\title{
Effectiveness and profitability of insecticide formulations used for managing snap bean pests
}

\author{
M. Otim I, M. Kasina ${ }^{2}$, J. Nderitu', M. Katafiire ${ }^{4}$, M. Mcharo ${ }^{5}$, M. Kaburu ${ }^{6}$, G. Bwire ${ }^{7}$, \\ J. Bwire', G. Cheminingw' ${ }^{3}$, F. Olubayo ${ }^{3}$ and M. Ugen ${ }^{8}$ \\ ${ }^{1}$ National Crops Resources Research Institute, Namulonge, P. O. Box 7084, Kampala, Uganda \\ ${ }^{2}$ Entomology Section, Kenya Agricultural Research Institute, NARL-Kabete, P. O. Box 14733-00800, \\ Nairobi, Kenya \\ ${ }^{3}$ Department of Plant Science and Crop Protection, University of Nairobi, P. O. Box 29053-00625, \\ Nairobi, Kenya \\ ${ }^{4}(\mathrm{RIP})$ \\ ${ }^{5}$ Private Bag, P. O. Box 38561 - 00623, Nairobi, Kenya \\ ${ }^{6}$ Ministry of Agriculture, Meru County, P. O. Box 1705, Meru 60100, Kenya \\ ${ }^{7}$ International Potato Center (CIP) -Uganda, P. O. Box 22274, Kampala, Uganda \\ ${ }^{8}$ National Semi-Arid Resources Research Institute (NaSARRI), P. O. Soroti, Serere, Uganda
}

Author for correspondence: motim9405@gmail.com, hotim@ nacrri.go.ug

\begin{abstract}
Snap bean (Phaseolus vulgaris L.) farmers rely mostly on insecticides to manage pests and to satisfy the stringent market requirements for insect and blemish-free pods. However, the cost of these pesticides lowers farm incomes. In addition, heavy and wrong use of pesticides could result in residue accumulation, which reduces market access by the farmers. To identify optimal pest control with lower economic risks to farmers, we investigated the effectiveness and profitability of different insecticides and insecticide formulations against bean fly (Ophiomyia spp.) and bean flower thrips (Megalurothrips sjostedtii). Two separate experiments were conducted during 2009 to 2012. The first experiment targeted bean fly and bean flower thrips, comprising the treatments: seed dressings, soil drenches, foliar sprays and an untreated control. We used randomised complete block design, with four replicates. All the seed dressing and soil drenching insecticides, except Apron, significantly lowered bean fly infestation by two to 60 fold when compared with control. These insecticides, however, did not control flower thrips. Confidor ${ }^{\circledR}$ resulted in a marginal returns of 0.89 and Actara ${ }^{\circledR}-\mathbf{- 0 . 1 1}$ compared to seed dressings, which ranged from 0.47 to 1.82. The second experiment laid in a randomised complete block design involved the foliar application of Roket ${ }^{\circledR}$ under different spray regimes. Application of Roket ${ }^{\circledR}$ reduced infestation of thrips, and resulted in positive MRR in all the seasons.
\end{abstract}

Key words: Frankliniella occidentalis, marginal rate of returns, Megalurothrips sjostedtii, Neonicotinoids, Ophiomyia phaseoli 


\section{Introduction}

Snap bean (Phaseolus vulgaris L.) also referred to as French bean or green bean -is produced in east Africa mainly for the export market. There is also increasing local consumption in the region. Uganda and Kenya exported 5,239 and 96,772 metric tonnes of green beans valued at US\$ 1.822 and 96.772 in 2013, respectively (FAO, 2016). Like other legumes, snap bean provides dietary protein in the form of immature fresh pods and is rich in iron, which is an important mineral for expectant and lactating mothers. Being predominantly a commercial crop, snap bean has a potential to increase incomes and living standards of small scale farmers, who form majority of producers.

Insect pests and diseases, however, pose a major challenge in the production of snap bean in East Africa. Bean flies (Ophiomyia spp) and thrips (Frankliniella occidentalis and Megalurothrips sjostedtii) are the most important insect pests of beans in the region (CIAT, 1992; Nderitu et al. 2001). Bean fly females lay eggs on the upper surface of the leaf. Hatched maggots mine through the leaf petioles and stems, and pupate below the epidermis of the stem at or above the ground level in seedlings, or at the base of the petiole in older plants. Pupation causes cracks, which weaken the plant, and also act as entry points for pathogens. Bean fly damage may result in seedling death under severe infestation (Abate and Ampofo, 1996). In contrast, flower thrips start infesting at the vegetative stage and migrate later into flower buds and flowers (Kasina et al., 2009). Thrips infestation levels were higher in snap beans planted in the first dry season (January 2002) than in the second dry season (July 2002) in Mwea-
Tebere (Kasina et al 2009). Damage by flower thrips results in premature fall of flower buds and flowers. This was estimated to cause $40 \%$ yield loss. In addition, feeding damage leads to $20 \%$ loss at collection points (Lohr, 1996).

In order to avert pest damage, farmers in Uganda and Kenya practice routine spray every one or two weeks to control pests, often spraying 8 to 15 times in a season (Nderitu et al., 2001; Makokha et al., 2001; Otim et al., 2011). Repeated sprays are time and labour consuming, increase cost of production, lead to secondary pest problems, insecticide resistance buildup, undesirable accumulation of pesticide residue in the produce, and pesticide poisoning (Seif $e t$ al., 2001; Nderitu et al., 2008; Oesterlund et al 2014). Exposure to agrochemicals was estimated to cause poisoning of approximately three million agricultural workers each year globally, and about 300,000 deaths (Gunnel et al. 2007). Pesticide use alone was estimated to account for $14 \%$ percent of the total production costs (Nyambo, 2006). This reduces the profit margins. The case of high residue in produce has resulted into interception of produce and trade barriers (Agritrade, 2013).

These drawbacks have heightened the need to shift from persistent insecticides and reduce the frequency of pesticide application on snap bean, and hence, adopt the concept of Integrated Pest Management (IPM). Therefore, less persistent insecticides such as neonicotinoids, applied in different ways, have been promoted in the past to offer better protection of snap beans against the pests. The systemic activity of neonicotinoids provides an alternative to organophosphates (Wyman and Chapman, 2004) in view of the strict snap bean 
export requirements. Use of systemic seed dressing and soil drenching insecticides can cut down the number of sprays by protecting the crop for up to nine weeks of growth (Bethke and Redak, 1997; Wyman and Chapman, 2004). This could be complemented with a few applications of foliar sprays after five weeks to protect against flower and pods pests such as thrips. This intervention would reduce growers' production costs, and improve human and environment safety (Nault et al., 2004). Considering the level off operation, seed dressing and onward sowing does not result in pesticide dust formation, hence has practically minimal effects on bees and other pollinators. Well-timed and fewer application of foliar sprays would not have significant effect on pollinators.

In this study, we evaluated the effectiveness and profitability of neonicotinoid insecticide formulations and a pyrethroid and organophosphate combination in snap bean pest control across seasons. The economic assessment is geared towards enabling farmers make informed decisions on the choice of insecticides.

\section{Materials and methods}

Studies were carried out under the framework of a regional project funded by the Association for Strengthening Agricultural Research in East and Central Africa (ASARECA) supporting research in Uganda, Kenya, Tanzania and Rwanda. In this undertaking, we use studies in Kenya and Uganda as case studies. We conducted studies on seed dressing and soil drenching in Kenya, while the foliar spray experiment was conducted in Uganda. These were based on the premise that information generated from one country has potential utility in another, and would only require validation of the results.

\section{Seed dressing and soil drenching}

The study was carried out at Kimbimbi in Mwea, Kirinyaga South District in Central Kenya for three seasons, 2009-2011. The site has an elevation of $1214 \mathrm{~m}$ a.s.l. while its geographical location is $0^{\circ} 36^{\prime} 21.66^{\prime \prime} \mathrm{S}$ and $37^{\circ} 22^{\prime} 01.24 " \mathrm{E}$ (Google, 2010). The area is a main centre for small-scale export snap beans production in Kenya. It is a warm lowland area, which records minimum and maximum temperatures of $17^{\circ} \mathrm{C}$ and $26^{\circ} \mathrm{C}$, respectively. Annual rainfall ranges from 356 to $1,625 \mathrm{~mm}$ with an average of $950 \mathrm{~mm}$ per year. The rainfall pattern is bimodal, with first rains coming in April/May and second rains in the months of October/December. Relative humidity varies from 52 to $67 \%$ (Manene, 2010).

The trial was planted in a randomised complete block design, with three replicates. Each block consisted of seven plots, giving a total of 21 plots. The plots measured $3 \mathrm{~m} \times 3 \mathrm{~m}$ which were separated by $0.5 \mathrm{~m}$ between plots and $1 \mathrm{~m}$ between blocks. Four seed dressing chemicals were used namely Gaucho ${ }^{\circledR} 350 \mathrm{FS}$, Monceren ${ }^{\circledR}$ GTF 390 Apron ${ }^{\circledR}$ Star 42WS and Cruiser ${ }^{\circledR} 350 \mathrm{FS}$ (Table 1). Application rates were $2 \mathrm{~g}, 8 \mathrm{ml}, 2.5 \mathrm{~g}$ and $4 \mathrm{ml}$ per $\mathrm{kg}$ of seed for Gaucho, Monceren, Apron and Cruiser, respectively. The seed and chemical were put in a $10 \mathrm{~cm} \times 15 \mathrm{~cm}$ clear polythene bag of gauge $150 \mu \mathrm{m}$ and a few drops of water added and then shaken continuously until the seeds were fully coated with the chemical. The seeds were then dried out on newspapers for three hours under shade, and planted the same day. In addition, two more chemical formulations (Confidor ${ }^{\circledR}$ WG70 and 
Table 1. Chemicals and rates used on snap beans in Mwea, Kenya

\begin{tabular}{|c|c|c|c|}
\hline Trade name & Chemical name & Active ingredient & Rate applied (/kg of seed or $\left.\mathrm{m}^{2}\right)$ \\
\hline Gaucho $^{\circledast} 350 \mathrm{FS}$ & Imidacloprid & Imidacloprid $350 \mathrm{~g} / \mathrm{l}$ & $7 \mathrm{~g}$ \\
\hline Monceren ${ }^{\circledR}$ GTF390 & Imidacloprid & $\begin{array}{l}\text { Imidacloprid } 233 \mathrm{~g} / 1+\text { Pencycuron } 50 \mathrm{~g} / 1 \\
+ \text { Thiram } 107 \mathrm{~g} / 1\end{array}$ & $8 \mathrm{ml}$ \\
\hline Apron $^{\circledR}$ Star 42WS & Thiamethoxam & $\begin{array}{l}20 \% \text { w/w Thiamethoxam }+20 \% \mathrm{w} / \mathrm{w} \\
\text { Metalaxyl-m }+2 \% \text { w/w Difenoconazole }\end{array}$ & $2.5 \mathrm{~g}$ \\
\hline Cruiser $^{\circledR}$ 350FS & Thiamethoxam & Thiamethoxam $250 \mathrm{~g} / \mathrm{kg}$ & $4 \mathrm{ml}$ \\
\hline Confidor $^{\circledR}$ WG70 & Imidacloprid & Imidacloprid $700 \mathrm{~g} / \mathrm{kg}$ & Soil drench $0.5 \mathrm{ml} / \mathrm{m}^{2}$, foliar spray $5 \mathrm{~g}$ per 20 litre water \\
\hline Actara $^{\circledR} 25 \mathrm{WG}$ & Thiamethoxam & Thiamethoxam $250 \mathrm{~g} / \mathrm{kg}$ & Soil drench $0.28 \mathrm{ml} / \mathrm{m}^{2}$, foliar spray $8 \mathrm{~g}$ per 20 litre water \\
\hline
\end{tabular}

Source: Product labels 
Actara $^{\circledR}$ 25WG) were assessed, as soil drench as alternative to seed dressing (Table 1). Both were drenched twice at three days after emergence; followed by a foliar spray ten days later. Soil drenching with Confidor was done on the surface after diluting with water at a rate of 0.5 $\mathrm{ml}$ per $\mathrm{m}^{2}$ (5 g in 10 litres); followed by foliar spray at a rate of $5 \mathrm{~g}$ in 20 litres. Actara drench was done along the bean rows, at a rate of $0.28 \mathrm{~g} \mathrm{~m}^{-2}$ and foliar spray at a rate of $8 \mathrm{~g}$ per 20 litres of tap water. Polythene sheets were placed on both sides of a plot to shield neighboring plots against drift.

Di-Ammonium phosphate (DAP) fertiliser was applied at planting, at a rate of $133 \mathrm{~kg} \mathrm{ha}^{-1}$ and Calcium Ammonium Nitrate (CAN) as top dressing at 35 days after emergence at the same rate. The plots were ridged at a spacing of $60 \mathrm{~cm}$, giving six furrows per plot. DAP was put in furrows and mixed with soil, then a single seed planted in small holes made by a stick at the edge of the furrow at 10 $\mathrm{cm}$ apart. This gave about 180 seedlings at emergence. Diseases were controlled

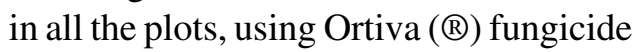
against angular leaf spot and Thiovit (®) fungicide against powdery mildew. All agronomic practices such as weeding, irrigation and fungal disease control were uniformly applied to all the plots. Supplemental irrigation was applied by flooding the furrows when the rains were insufficient.

\section{Foliar application}

This experiment was conducted at the National Crops Resources Research Institute, NaCCRI, in Namulonge, Wakiso, Uganda. It is located at $0032^{\prime \prime} \mathrm{N}$ of the Equator and $32^{\circ} 37^{\prime \prime}$ E. It is $27 \mathrm{Km}$ North of Kampala at an elevation of 1150 metres above-sea- level. It has a tropical wet and mild dry climate with slightly humid conditions (average 65\%), with two rainy seasons (Yada et al., 2010). This location is ideal for evaluations on snap bean because; (i) it is located in the snap bean growing area in the country; and (ii) the two rainy seasons of approximately the same length (3 months each) offer the chance to carry out trials twice a year.

The experiment was conducted between 2009 and 2012. Treatments comprised five spray intervals $(5,10,15$, 20, 25 days) of Roket $\AA$ (Profenofos $40 \%$ + Cypermethrin 4\%) and an untreated control. Roket ${ }^{\circledR}$ was used because it is the most widely used pesticide in vegetable production in Uganda (Otim et al., 2011). The treatments were laid in a randomized complete block design (RCBD), replicated four times, making a total of 24 plots. The gross experimental area was $37 \mathrm{~m} \mathrm{x} 25 \mathrm{~m}\left(925 \mathrm{~m}^{2}\right)$ and the net experimental area was $30 \mathrm{~m} \times 20 \mathrm{~m}$ $\left(600 \mathrm{~m}^{2}\right)$. Each plot had dimensions of $5 \mathrm{~m}$ x $5 \mathrm{~m}\left(25 \mathrm{~m}^{2}\right)$. Plant spacing was $30 \mathrm{~cm}$ between rows and $10 \mathrm{~cm}$ between plants. Roket ${ }^{\circledR}{ }^{\circledR}$ was applied at rate of $30 \mathrm{ml}$ per $15 \mathrm{~L}$ of tap water, starting at two weeks after planting. Agro-zeb ${ }^{\circledR}$ (80\% WP, AIMancozeb 80\%) was applied regularly at a rate of $30 \mathrm{~g}$ per $15 \mathrm{~L}$ of water to protect against fungal diseases. All these amounts were calculated from instructions on the users' manual.

\section{Data collection}

Seed dressing and soil drenching. Data were collected on bean fly oviposition punctures, immature (larvae and pupae) and pod yield. The oviposition punctures were counted weekly from 15 leaves, randomly picked per plot from the inner four lines. The number of maggots/ pupae in bean stems was scored by randomly uprooting five plants per plot, at 
three and five weeks after emergence. The stems were then dissected and the number of maggots/pupae recorded. Thrips on leaves were counted with the aid of a hand lens. To count thrips on flowers, 15 fully open flowers were randomly picked per plot then inserted into bottles containing $50 \%$ alcohol. The flowers were taken to the laboratory where they were macerated carefully in $50 \%$ alcohol to extract all the thrips, which were then counted and recorded for each plot. At harvest, green pods were picked from the entire plot twice a week from week six to week twelve, washed and graded into marketable and unmarketable lots.

Foliar application. In this experiment, we collected data on thrips infestation and pod yield. Thrips infesting French beans were randomly collected on 10 flowers from the inner rows of each plot. This was done at an interval of three days from first appearance of flower buds and continued throughout the flowering period. Samples were preserved in $70 \%$ ethanol solution for processing. The contents were handled as described above.

\section{Data analysis}

Data on the number of insects were analysed using GenStat Software $\left(14^{\text {th }}\right.$ edition), using analysis of variance (ANOVA). Means were separated using the Least Significant Difference (LSD) at $\mathrm{P}<0.05$.

\section{Profitability analysis}

Profitability in both experiments was calculated using the gross marginal rate of returns. This is the ratio of net returns to the cost of control. The net rate of returns were calculated by subtracting the total cost incurred for each spray regime used from the corresponding gross returns obtained from selling French bean pods. At the time of the experiment, the farm gate price of French beans was Uganda shillings 3,000 per kilogramme, equivalent to US\$ 1.215 . The cost of $1 \mathrm{~L}$ Roket ${ }^{\circledR}$ was USD 16. The cost of pesticides was obtained from the purchase price and computed to a hectare while the cost of application was obtained from the farmers and researcher's own records.

\section{Results}

\section{Seed dressing on bean flies and thrips infestation}

The number of bean fly immatures was significantly $(\mathrm{P}<0.001)$ different across the treatments in 2009 and 2011 plantings (Table 2). Snap beans in plots treated with soil drenching insecticides (Confidor and Actara) consistently recorded the lowest bean fly infestation levels, when compared to the seed dressing chemicals and the untreated control. The effect of the seed dressing chemicals, Gaucho and Cruiser, resulted into significantly lower bean fly infestation. The effects of Monceren and Apron star, drenching was significantly better in the control of bean fly compared with seed dressing. Control had the highest number of bean flies compared with the chemicals though bean flies on snap beans treated with some seed dressers were not significantly different from those in control.

Thrips infestation on snap beans treated with seed dressing and soil drenching insecticides was significantly different in the first and third season (Table 3). Snap beans treated with Apron star (seed dresser) recorded the highest mean number of thrips while those treated with Confidor (soil drenching) recorded the lowest infestation in the first planting. However, in the third planting, Actara (soil 
Effectiveness and profitability of insecticide formulations

Table 2. Mean number of bean fly immatures infesting French beans under different insecticide treatments at Mwea, Central Kenya in 2009, 2010 and 2011

\begin{tabular}{llclc}
\hline Insecticide & Mode of application & 2009 & 2010 & 2011 \\
\hline Confidor & Soil drenching & 0 & 0 & 0.5 \\
Actara & & 0 & 0.3 & 0.8 \\
& & & & \\
Gaucho & Seed dressing & 11.2 & 0.8 & 4.7 \\
Monceren & & 16.8 & 1.2 & 7.0 \\
Cruiser & 20.0 & 0.7 & 4.7 \\
Apron Star & 34.3 & 1.0 & 3.3 \\
Control & 30.8 & 2.8 & 6.2 \\
& & & \\
P - value & & $<0.001$ & 0.06 & $<0.001$ \\
SEM & 4.21 & 0.559 & 1.033 \\
\hline
\end{tabular}

Table 3. Mean number of flower thrips infesting French beans under different insecticide treatments at Mwea, Central Kenya in 2009, 2010 and 2011

\begin{tabular}{lcccc}
\hline Insecticide & Mode of application & 2009 & 2010 & 2011 \\
\hline Confidor & Soil drenching & 6.9 & 18.3 & 63.4 \\
Actara & & 7.0 & 23.3 & 66.3 \\
& & & & \\
Gaucho & Seed dressing & 8.1 & 14.9 & 57.2 \\
Monceren & & 8.1 & 13.8 & 51.4 \\
Cruiser & & 10.2 & 13.8 & 50.6 \\
Apron Star & 12.3 & 11.3 & 44.6 \\
Control & 7.9 & 12.8 & 49.7 \\
& & 0.006 & 0.117 & 0.018 \\
P - value & & 0.06 & 0.172 & 0.098 \\
SEM & & &
\end{tabular}

drenching) treated snap beans had the highest thrips count while Apron star treated snap beans had the lowest. Overall, though not significant $(\mathrm{P}>0.05)$, seed dressing snap beans lowered thrips infestation compared with soil drenching and control.

The effect of foliar sprays on thrips infestation and snap bean yield

Thrips infestation on snap beans was significantly different between treatments in all the five seasons (Table 4). Overall, the lowest number of thrips was recorded in snap bean sprayed at $5 \mathrm{~d}$ interval, while the highest was recorded in the unsprayed plots. Spraying starting at $25 \mathrm{~d}$ after emergence resulted in lower infestation compared with other spray regimes $(10$, 15 and $20 \mathrm{~d}$ after emergence) in three plantings (2010B-1, 2010B-b and 2012A). Profitability of chemical control

Insecticides used for drenching were the most expensive in terms of purchase 
Table 4. Mean number of flower thrips infesting French beans under different spray intervals at NaCRRI, central Uganda in 2009, 2010, 2011 and 2012

\begin{tabular}{|c|c|c|c|c|c|c|}
\hline \multirow[t]{2}{*}{ Spray interval (days) } & $2010 \mathrm{~A}$ & 2010 B-1 & 2010 B-2 & $2011 \mathrm{~A}$ & $2012 \mathrm{~A}$ & $\begin{array}{c}\text { Overall } \\
\text { mean }\end{array}$ \\
\hline & --- & --- & Thrips pe & 0 flowers & --- & -- \\
\hline 5 & 26.2 & 10.9 & 29.9 & 20.4 & 24.7 & 20.3 \\
\hline 10 & 39.8 & 18.8 & 38.8 & 22.2 & 30.0 & 26.4 \\
\hline 15 & 22.3 & 35.2 & 44.4 & 25.5 & 57.5 & 32.9 \\
\hline 20 & 36.9 & 43.0 & 50.1 & 28.6 & 40.7 & 39.2 \\
\hline 25 & 45.2 & 13.4 & 26.5 & 34.0 & 29.2 & 27.9 \\
\hline No spray & 83.4 & 41.3 & 41.3 & 39.6 & 52.8 & 42.99 \\
\hline $\mathrm{P}$-value & $<0.001$ & $<0.001$ & 0.002 & $<0.001$ & $<0.001$ & $<0.001$ \\
\hline SEM & 0.0944 & 0.0605 & 0.0715 & 0.034 & 0.0459 & 0.05 \\
\hline
\end{tabular}

price as well as application cost (Table 5). Amongst the seed dressers, Gaucho was the most expensive while Cruiser was the least. Snap beans protected with drench applications had the highest yields with Confidor treated crops having more than doubled the yield of the second best yielding treatment. Snap beans treated with Confidor also had the highest net returns followed by those dressed with Monceren and Cruiser. Apron star seed dressed snap beans had the lowest net returns. However, considering marginal returns from the investment in different formulations, Cruiser provided the highest gains followed by Apron star and Monceren. Investment in Confidor provided just above half of the gains from using Cruiser. Actara had the lowest gains, in fact, negative gains. The unprotected snap beans (control) had the lowest yields and returns.

In the case of foliar sprays, snap beans that received more insecticide sprays produced the highest marketable yield while those that received less sprays had the lowest amongst the insecticide treatments (Table 6). Unprotected snap beans had the lowest crop yield. The marginal rate of return was always positives and not consistent across plantings. In the first planting of 2010A and second planting of 2010B, MRR was less than unity for all the spray applications. In the first planting of 2010B and 2011, however, plots that received between $2-4$ spray applications of Roket had MRR of one. In 2012, only the plots that received two spray applications had a MRR of one, all the rest had less than one.

\section{Discussion}

Our results have shown that use of neonicotinoids as soil drench and seed dressing can effectively reduce severity of bean fly but may not manage thrips. Confidor and Actara were the most effective chemicals in controlling bean fly as shown by the low numbers of maggots and high yields. This is similar to earlier work on Borboti bean that showed that Actara soil mix was effective against bean fly (Rahman and Prodhan, 2007). Gaucho and Cruiser seed dressings were 
Effectiveness and profitability of insecticide formulations

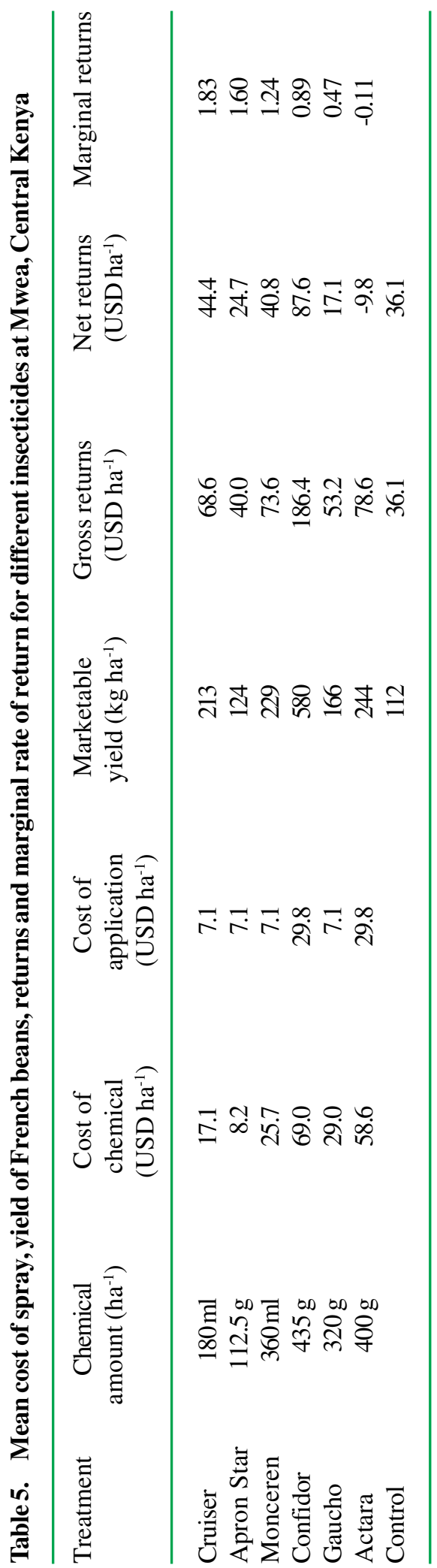

moderately effective whereas effect of Monceren and Apron Star were not consistent. The yield of various plots reduced with increased maggot/pupae infestation as reported by Peter et al. (2009) on common beans. Thus, failure to put in place any bean fly control strategy can lead to uneconomic yields (Seif et al., 2001). Effectiveness of these seed dressing chemicals (Gaucho and Cruiser) may be enhanced by combining with cultural and biological management techniques in an integrated pest management system (Infonet-Biovision, 2010, Seif et al., 2001). Ogecha et al. (2000) reported that combination of seed dressing with cultural techniques can increase crop tolerance to bean fly and improve crop yields. This is corroborated in similar work by Ampofo and Massomo (1998) on dry beans in Tanzania who found that combination of cultural techniques with seed dressing is more effective than seed dressing alone. However, spraying starting at $25 \mathrm{~d}$ interval resulted in lower thrips infestation and higher MRR. This period coincides with flower bud formation and therefore curtailing the buildup of thrips.

Our study showed that neonicotinoid seed dressings and soil drenches, followed with a spray application were not effective in controlling bean flower thrips. In contrast, Nayasani et al. (2015) found that Imidacloprid reduced the number of Western Flower thrips on French beans plants and in flowers. Similarly, Seal et al (2006) demonstrated that Imidacloprid significantly suppressed both adults and larvae of chilli thrips Scirtothrips dorsalis (Hood) on pepper in the field for at least 15 days. This may be explained by the differences in timing and number of insecticide application. In our study, we applied Imidacloprid as a soil drench and 
Table 6. Mean marketable yield, returns, cost of sprays and marginal rate of return under different spray regimes at NaCRRI, Uganda

\begin{tabular}{lcccccc}
\hline $\begin{array}{l}\text { No. sprays/ } \\
\text { Season }\end{array}$ & $\begin{array}{c}\text { Cost of } \\
\text { chemical } \\
\left(\mathrm{USD} \mathrm{ha}^{-1}\right)\end{array}$ & $\begin{array}{c}\text { Cost of } \\
\text { application } \\
\left(\mathrm{USD} \mathrm{ha}^{-1}\right)\end{array}$ & $\begin{array}{c}\text { Marketable } \\
\text { yield } \\
\left(\mathrm{kg} \mathrm{ha}^{-1}\right)\end{array}$ & $\begin{array}{c}\text { Gross returns } \\
\left(\mathrm{USD} \mathrm{ha}^{-1}\right)\end{array}$ & $\begin{array}{c}\text { Net returns } \\
\left(\mathrm{USD} \mathrm{ha}^{-1}\right)\end{array}$ & $\begin{array}{c}\text { Marginal } \\
\text { returns }\end{array}$ \\
\hline
\end{tabular}

\begin{tabular}{|c|c|c|c|c|c|c|}
\hline \multicolumn{7}{|c|}{$2010 \mathrm{~A}$} \\
\hline 11 & 4.4 & 330.1 & 837.4 & $1,004.9$ & 670 & 0.7 \\
\hline 6 & 2.4 & 180.1 & 1369.0 & $1,642.8$ & 1,460 & 0.9 \\
\hline 4 & 1.6 & 120.0 & 1172.7 & $1,407.3$ & 1,286 & 0.9 \\
\hline 3 & 1.2 & 90.0 & 917.1 & $1,100.5$ & 1,009 & 0.9 \\
\hline 2 & 0.8 & 60.0 & 767.1 & 920.5 & 860 & 0.9 \\
\hline Control & & & 788.1 & 945.8 & & \\
\hline \multicolumn{7}{|c|}{2010 B-1 } \\
\hline 11 & 4.4 & 330.1 & 2716.8 & $3,260.1$ & 2,926 & 0.9 \\
\hline 6 & 2.4 & 180.1 & 2702.6 & $3,243.2$ & 3,061 & 0.9 \\
\hline 4 & 1.6 & 120.0 & 2586.8 & $3,104.2$ & 2,983 & 1.0 \\
\hline 3 & 1.2 & 90.0 & 2212.4 & $2,654.8$ & 2,564 & 1.0 \\
\hline 2 & 0.8 & 60.0 & 3069.3 & $3,683.2$ & 3,622 & 1.0 \\
\hline Control & & & 2174.6 & $2,609.5$ & & \\
\hline \multicolumn{7}{|c|}{2010 B-2 } \\
\hline 11 & 4.4 & 330.1 & 1060.7 & $1,272.8$ & 938 & 0.7 \\
\hline 6 & 2.4 & 180.1 & 868.3 & $1,041.9$ & 859 & 0.8 \\
\hline 4 & 1.6 & 120.0 & 1031.5 & $1,237.8$ & 1,116 & 0.9 \\
\hline 3 & 1.2 & 90.0 & 1035.2 & $1,242.3$ & 1,151 & 0.9 \\
\hline 2 & 0.8 & 60.0 & 717.7 & 861.3 & 800 & 0.9 \\
\hline Control & & & 1130.4 & $1,356.5$ & & \\
\hline \multicolumn{7}{|c|}{2011} \\
\hline 11 & 4.4 & 330.1 & 1964.7 & $2,357.6$ & 2,023 & 0.9 \\
\hline 6 & 2.4 & 180.1 & 2507.1 & $3,008.5$ & 2,826 & 0.9 \\
\hline 4 & 1.6 & 120.0 & 2663.0 & $3,195.7$ & 3,074 & 1.0 \\
\hline 3 & 1.2 & 90.0 & 2587.7 & $3,105.3$ & 3,014 & 1.0 \\
\hline 2 & 0.8 & 60.0 & 2383.1 & $2,859.7$ & 2,799 & 1.0 \\
\hline Control & & & 2372.7 & $2,847.2$ & & \\
\hline \multicolumn{7}{|c|}{2012} \\
\hline 11 & 4.4 & 330.1 & 1823.8 & $2,188.5$ & 1,854 & 0.8 \\
\hline 6 & 2.4 & 180.1 & 1324.0 & $1,588.8$ & 1,406 & 0.9 \\
\hline 4 & 1.6 & 120.0 & 1181.2 & $1,417.5$ & 1,296 & 0.9 \\
\hline 3 & 1.2 & 90.0 & 1477.7 & $1,773.2$ & 1,682 & 0.9 \\
\hline 2 & 0.8 & 60.0 & 1403.6 & $1,684.3$ & 1,624 & 1.0 \\
\hline Control & & & 1167.2 & $1,400.6$ & & \\
\hline
\end{tabular}

*The cost of sprays includes cost of purchasing insecticide and labour for spraying 
followed with a single foliar spray 10 days later. Thus in our study, the pest might have appeared when the Imidacloprid had become in effective. Nyasani et al. (2015), however, applied Imidacloprid three times at $14 \mathrm{~d}$ interval, starting at budding. This targeted the stage when the thrips were most abundant. This necessitates insecticide application as and when required following the loss of efficacy of seed dressing or soil drenching insecticides.

The results of our foliar application showed that increased frequency lowered thrips population, with five day interval being the most effective. This may in effect explain the dependence of farmers on frequent insecticide application and their rating as effective (Nderitu et al., 2008; Otim et al. 2011).

Our studies have shown that seed dressing, soil drenching and foliar pesticide application are effective in lowering pest populations. However, producers have to be mindful of the profitability and dangers associated with their use. From our studies, Confidor and Actara were the most effective in controlling bean fly and gave the highest pod yields. However, the two were not the most profitable. For instance, application of Actara resulted to negative marginal rate of returns. Similarly, lower spray interval of Roket ${ }^{\circledR}$ resulted into lower marginal returns when compared to longer intervals. CalderónLimón et al. (2002)reported that farmers who applied higher than the recommended concentrations of insecticide to control pests on hot pepper did not realize yield advantage. As argued by Karungiet al. (2000) and Nderitu et al. (2008), fewer sprays of insecticide are the most costeffective for management of major field pests of cowpea and snap beans, respectively. In order to achieve these few sprays, farmers should be guided by the thrips density or numbers. This requires developing economic injury levels and monitoring of the thrips build up in the season and only use insecticides when the thrips attain the action threshold level. This is possible when farmers can easily identify flower thrips (Nderitu et al., 2001), or can be taught to do so. This will enable French bean farmers to gain from their investments economically, while maintaining the required market standards. Apart from economic benefits, few applications of insecticides have other benefits to the farmers themselves, the environment, as well as the consumers of the French bean product. Few sprays minimize the likelihood of pesticide residues on the crop produce, ground water sources, environment pollution as well as the negative effects on natural enemies. French bean pods are harvested continuously as the crop flowers and as such few applications would not endanger pickers.

The current global trends in the use of pest control products suggests promoting those products with low or no effect on humans and the environment. The reported decline of honey bees in North America and Europe is now a major concern and efforts to halt this have been suggested. One of the effects on bees is the use of neonicotinoids (e.g. Whitehorn et al., 2012) and recommendations have been made to reduce their use in agriculture (e.g. Hopwood et al., 2013). Thus, extension of knowledge about the effects of neonicotinoids on bees and other pollinators in East Africa should be explored. Among the European Union countries, France made a request on emergency measures relating to the potential risk of dimethoate and its derivatives. The European Food Safety 
Authority (2016) recommended a comprehensive review of the existing EU MRLs to derive a final opinion on possible risks for consumers resulting from residues of dimethoate and its metabolites in food. We also recommend testing new chemistries and other consumer preferred insecticides for effectiveness and profitability.

\section{Conclusion}

Since the aim of small-scale farmers is to make profits at reduced costs, expensive chemicals such as Confidor and Actara and regular applications should be avoided. For bean fly control, Cruiser and Apron star are the most profitable and recommended options. In addition, two to three applications of foliar insecticide may suffice for control of thrips.

\section{Acknowledgement}

The study was made possible through a grant from ASARECA (FP05-UgenIRCO4-C1-01). Views expressed in this article are not necessarily those of ASARECA but authors. We thank our institutional management for their technical administrative support.

\section{References}

Abate, T. and Ampofo, J.K.O. 1996. Insect pests of beans in Africa: Their ecology and management. Annual Review of Entomology 41:45 - 73.

AgriTrade. 2013. New EU maximum residue levels hit Kenyan vegetable exports.

Ampofo, J.K.O. and Massomo, S.M. 1998. Some cultural strategies for management of bean stem maggots (Diptera: Agromyzidae) on beans in
Tanzania. African Crop Science Journal 6(4): 351-356.

Bethke, J. A. and Redak, R. 1997. Effect of Imidacloprid on the silverleaf whitefly, Bemisia argentifolii Bellows and Perring (Homoptera: Aleyrodidae), and whitefly parasitism. Annals of Applied Biology 130: 397-407.

CIAT (Centro Internationale de Agricultura Internationale). 1992. Snap beans in the developing world. In: Henry, G. and Janssen, W. (Eds.). Proceedings of an international conference. CIAT, Cali, Colombia. 366pp.

EFSA (European Food Safety Authority). 2016. Assessment of the risk to human health through the pesticide active substance for dimethoate and its metabolites in food. EFSA Journal 14 (4):4461, 38 pp. doi:10.2903/ j.efsa.2016.4461

Gunnell, D., Eddleston, M., Phillips, M.R. and Konradsen, F. 2007. The global distribution of fatal pesticide selfpoisoning: systematic review, $B M C$ Public Health 7(c):357. doi:10.1186/ 1471-2458-7-357.

Hopwood, J., Vaughan, M., Shepherd, M., Biddinger, D., Mader, E., Black, S.H. and Mazzacano, C. 2013. Are neonicotinoids killing bees? A review of research into the effects of neonicotinoid insecticides on bees, with recommendations for action. http:// www.xerces.org/neonicotinoids-andbees/ (Accessed May 20, 2013)

Infonet-biovision. 2010. Farmer Information Platform (4 ${ }^{\text {th }}$ Edition) March 2010. www.infonet-biovision. org. Accessed 28 ${ }^{\text {th }}$ March 2011

Karungi, J., Adipala, E., Kyamanywa, S., Ogenga- Latigo, M.W., Oyobo, N. and Jackai, L.E.N. 2000. Pest 
management in cowpea. Part 2 . Integrating planting time, plant density and insecticide application for management of cowpea field insect pests in eastern Uganda, Crop Protection 19:237-245.

Kasina, M., Nderitu, J., Nyamasyo, G., Waturu, C., Olubayo, F. and Obudho, E. 2009. Within-plant distribution and seasonal population dynamics of flower thrips (Thysanoptera: Thripidae) infesting French beans (Phaseolus vulgaris L.) in Kenya, Spanish Journal of Agricultural Research 7(3):652-659.

Lohr, B. 1996. Integrated pest management in French beans in Kenya: Past achievements and some thoughts about the flower thrips problem. Proceedings of the Biennial Crop Protection Conference. 27-28 March 1996, Nairobi, Kenya.

Makokha, A.O., Ombwara, F.K., Wamocho, L.S, Wesonga, J.M. and Sichangi, P. 2001. Farming characteristics among small scale French bean (Phaseolus vulgaris L.), farmers in Mwea, Kenya. In: J.M. Wesonga, T., Losenge, C.K. Ndungu, K., Ngamau, F.K. Ombwara and S.G. Agonga (Eds.), Proceedings of the first horticultural seminar on sustainable horticultural production in the tropics. JKUAT, Nairobi, Kenya. pp. $106-111$

Manene, S.K. 2010. Kirinyaga South District briefs. Ministry of Agriculture. Wanguru. Kenya.

Nault, B.A., Taylor, A.G., Urwiler, M. Rabaey, T. and Hutchison, W.D. 2004. Neonicotinoid seed treatment for managing Potato leafhopper in snap bean, Crop Protection 23: 147-154.

Nderitu, J.H., Kasina, M.J., Nyamasyo, G.N., Waturu, C.N. and Aura, J. 2008.
Management of thrips (Thysanoptera: Thripidae) on french beans (Fabacae) in Kenya: Economics of insecticide applications. Journal of Entomology, 5 (3): 148-155.

Nderitu, J.H., Olubayo, F., Waturu, C.N., Aura, J. and Kasina, J. 2001. Current french bean pests and disease management at Mwea Tebere, Central Kenya. In: J.M. Wesonga, T. Losenge, C.K. Ndung'u, K. Ngamau, F.K. Ombwara, S.G. Agong, A. Fricke, B. Hau and Stützel $\mathrm{H}$ (Eds.), Proceedings of the Horticulture seminar on Sustainable Horticultural Production in the Tropics. JKUAT and Hannover, Nairobi, Kenya. pp. 118-122.

Nyambo, B. 2006. Developing country initiative. Pesticide News 71. March 2006. $2 \mathrm{p}$

Nyasani, J., Subramanian, S., Poehling, H.M., Maniania, N., Ekesi, S. and Meyhöfer, R. 2015. Optimizing western flower thrips management on french beans by combined use of beneficials and imidacloprid. Insects 6(1):279-296. http://doi.org/10.3390/ insects6010279

Oesterlund, A.H., Thomsen, J.F., Sekimpi, D.K., Maziina, J. and Racheal, A. Jrs E. 2014. Pesticide knowledge, practice and attitude and how it affects the health of small-scale farmers in Uganda: A cross-sectional study. African Health Science 14(2):420433. doi:10.4314/ahs.v14i2.19.

Ogecha, J. and Ampofo, J.K.O. 2000. Development of an Integrated Pest Management strategy for controlling bean stem maggot in South Western Kenya. Participatory technology development for soil management by small holders in Kenya. In: Proceedings of the $2^{\text {nd }}$ Scientific 
Conference of the Soil Management and Legume Research Network Projects. Kenya Agricultural Research Institute Mombasa, Kenya pp. 311-317.

Otim, M., Obia, P.O., Mugagga I. and Ugen, M. 2011. Famers' perceptions and management of pests and diseases on snap beans in Uganda. In: M. Katafiire, M. Ugen and Mwamburi Mcharo (Eds.), Proceedings of the Regional Stakeholders' Workshop. ASARECA, Entebbe, Uganda, pp. 8395.

Peter, K.H., Swella, G.B. and Mushobozy, D.M.K. 2009. Effect of plant populations on the incidence of bean stem maggot (Ophiomyia spp.) in common bean intercropped with maize. Plant Protection Science 45(4):148-155.

Rahaman, M.A. and Prodhan, M.D.H. 2007. Management of borboti bean fly (Ophiomyia spp.), International Journal of Sustainable Crop Production 2(3): 5-8.

Seal, D.R., Ciomperlik, M., Richards, M.L. and Klassen, W. 2006.
Comparative effectiveness of chemical insecticides against the chilli thrips, Scirtothrips dorsalis Hood (Thysanoptera: Thripidae), on pepper and their compatibility with natural enemies, Crop Protection 25:949-955.

Seif A., Varela, A.M., Michalik, S. and Lohr, B. 2001. A guide to IPM in French beans production with emphasis on Kenya. International Centre for Insect Physiology and Ecology, Nairobi, Kenya, 72pp

Whitehorn, P.R., O'Connor, S., Wackers, F.L. and Goulson, D. 2012. Neonicotinoid pesticide reduces bumble bee colony growth and queen production. Science 336: 351-352.

Wyman, J. and Chapman, S. 2004. Insecticide seed treatments for snap beans. http://www.soils.wisc.edu/ extension/wcmc/2004proceedings/ Wyman2.pdf.Accessed May 27, 2015. Yada, B., Tukamuhabwa, P., Alajo, A. and Mwanga, R.O.M. 2010. Morphological characterization of Ugandan sweet potato germplasm, Crop Science 50:2364-2371. 